Article

\title{
Park Accessibility Impacts Housing Prices in Seoul
}

\author{
Jin Han Park ${ }^{1}$, Dong Kun Lee ${ }^{1,2, *}$, Chan Park ${ }^{3, *}$, Ho Gul Kim ${ }^{1}$, Tae Yong Jung ${ }^{4}$ and \\ Songyi Kim ${ }^{5}$ \\ 1 Interdisciplinary Program in Landscape Architecture, Seoul National University, Seoul 08826, Korea; \\ cupidjh@gmail.com (J.H.P.); khgghk@snu.ac.kr (H.G.K.) \\ 2 Department of Landscape Architecture, College of Agriculture and Life Sciences, Seoul National University, \\ Seoul 08826, Korea \\ 3 Department of Landscape Architecture, College of Urban Science, University of Seoul, Seoul 02504, Korea \\ 4 Graduate School of International Studies, Yonsei University, Seoul 03722, Korea; tyjung00@gmail.com \\ 5 Tourism Policy Research Division, Korea Culture \& Tourism Institute, Seoul 07511, Korea; \\ skimtheory@gmail.com \\ * Correspondence: dklee7@snu.ac.kr (D.K.L.); chaneparkmomo7@uos.ac.kr (C.P.); \\ Tel.: +82-2-880-4875 (D.K.L.); +82-2-6490-2849 (C.P.)
}

Academic Editors: Karsten Grunewald and Olaf Bastian

Received: 31 October 2016; Accepted: 23 January 2017; Published: 27 January 2017

\begin{abstract}
Housing prices are determined by a variety of factors, including the features of the building and the neighborhood environment, and a potential buyer decides to buy a house after reviewing these factors and concluding that it is worth the price. We used Hedonic Price Methods to find the relationship between monetary value of house and access conditions to urban parks. Two meaningful results were discovered in this study: first, as the distance from the park increases, the value of the park inherent in the housing price decreases; second, the greater walking accessibility, to the park, the higher the park value inherent in housing prices. Despite presenting shorter distances to walk and more entrances, poorly accessible zones were deemed as such due to the necessity of crossing an arterial road. This indicates that the results can define accessibility not as the Euclidian distance but as the shortest walking distance while considering crossroads and park entrances. The results of this study have significant implications for urban park economic impact analyses in Seoul. Also, the increase in housing prices closer to parks supports the idea that access is dependent on the residents' socioeconomic status. Lastly, the results of this study can improve walking accessibility to the park.
\end{abstract}

Keywords: property price; valuation; ecosystem services; hedonic price methods (HPM); non-market value

\section{Introduction}

The number of visitors to the mountain-based national parks in South Korea rose from 25 million in 2007 to 41 million in 2012 [1]. These numbers suggest that individuals' attempts to resolve their dissatisfaction with their residential environment manifests in more involvement with nature [2], and parks play a crucial role in meeting this need [3]. Considering not only these situations in Korea but also those in an increasing number of cities around the world [4], the demand for cultural services is substantial, and makes relevant research necessary [4].

Green/blue spaces, such as urban parks, offer many ecosystem services [4-7], including climate regulation, water regulation, water supply, food, raw materials, aesthetic information, recreation, science and education $[4,8,9]$. For example, regulating services provided by urban parks contributes to resident well-being in cities. It can also help reduce urban heat island effects as well as mitigate climate change and air pollution [4]. 
Many people who use the park recognize the value of cultural services such as learning and education, cohesion and integration, entertainment and leisure, maintenance of cultural heritage, and exercise and physical recreation that the park provides $[5,6]$. Moreover, parks ameliorate stress, fear, and violence among the population $[10,11]$. Urban parks offer a variety of ecosystem services, especially cultural services related to well-being [4,12-15].

People consider several factors when choosing a house, and parks are an important factor in urbanized areas [16,17], since urban residents take advantage of the cultural services provided by the park [5]. People also prefer large parks and amenity parks [18]; however, there are differences in accessibility and equity of parks according to a resident's socioeconomic status [19-21].

The housing price is subject to a variety of factors, including building features and neighborhood environment, and a buyer only purchases a house after reviewing these elements and determining it is worth the price. For example, subway access and school districts affect housing prices [22], and surrounding green spaces or parks also change prices [23,24]. The value of various cultural services provided by parks are also incorporated in the housing price a resident may be considering [25-27].

The following research objectives were present in the study: First, how can the monetary value of parks' cultural ecosystem services be estimated? Second, are there differences in the recognized value of cultural services provided by parks depending on distance? Third, if so, what else can be done to improve the value of cultural services aside from reducing park distance? To this end, hedonic price methods and data provided by the Seoul Metropolitan Government for a case study of an urban park in Seoul are used.

\section{Literature Review}

\subsection{Hedonic Price Methods (HPM)}

The two methodologies most commonly used to evaluate nonmarket goods are Hedonic Price Methods (HPM) in revealed preference methods category and Contingent Valuation Methods (CVM) in stated preference methods category [28-31]. The difference between the two methods is whether the respondents reveal their preferences. CVM is typically used to estimate intangible value as determined through user surveys. However, we can presume that preferences are implicit in the price of the apartment selected, as people tend to prefer houses located near parks. Therefore, HPM is more suitable for estimating the value inherent in a preference [28,29]. In fact, many studies have used HPM to estimate the value of the ecosystem services, including parks, inherent in housing prices $[7,25,26,32-36]$

HPM is the study of the relationship between the price of a commodity or house and its characteristics $[28,29,37]$. For example, people buy real estate, such as an apartment or house, because they expect to gain utility and enjoyment from the house. In the case of an apartment, the age of the building, the size or number of rooms, and the presence of other amenities such as a fitness center, basement garage, and playground are also considered. Furthermore, the location of the house is important to residents; the distance from school or the office and recreation or entertainment facilities are examples of location characteristics. Moreover, the social and environmental attributes of the surrounding neighborhood are properly considered. These characteristics contribute to a resident's satisfaction with the house, and therefore affect the price they are willing to pay for it. The function of HPM in property is to determine the relationship between all of these characteristics and the price for which people are willing to buy the house. [29,37].

An important assumption inherent in microeconomics is that all goods are homogeneous; however, two goods can certainly bear different characteristics, even if in reality they are included in the same category of goods. HPM supposes that the price of goods is the sum of the characteristics' values, so any separation of their value based on market price involves HPM. The housing price, for example, contains the value of the environment as well as the value of the property itself $[27,28,38]$. 
For example, if the structural characteristics of the house are represented by $S_{i}$, the characteristics of the neighborhood in which the house is located by $N_{i}$ and the characteristics of specific environmental by $Q_{i}$, the housing price $P_{i}$ at location is given by the standard regression equation $[28,29,32,37]$ :

$$
P_{i}=\alpha+\beta S_{i}+\gamma N_{i}+\delta Q_{i}+\varepsilon
$$

\subsection{Variables}

Sander and Haight [32] used three categories of variables (characteristics of house, characteristics of neighborhood and characteristics of environment) to analyze the effect of Dakota County parks in Minnesota. Escobedo et al. [33] used two categories of variables, house characteristics and urban forest attributes, to estimate the effect of forest structures on property value. Roebeling et al. [7] and Payton et al. [34] also used three qualities of urban parks to value the benefits provided by city parks. Ko et al. [25] and Kim et al. [35] estimated the value of green space with three variable categories, which include attributes such as property area, age, size of apartment complex, school district, and accessibility to public transport and parks. Oh and Lee [26] and Hwang et al. [36] estimated the value of homeowners' rights to a view on housing price. Table 1 summarizes the variables discussed above.

Table 1. Variables of literature reviews.

\begin{tabular}{clc}
\hline Category & \multicolumn{1}{c}{ Variables } & References \\
\hline & Area of a house & {$[7,25,26,32-36]$} \\
& Number of bathroom & {$[25,33,34]$} \\
& Number of bedrooms & {$[25,33,34]$} \\
& House type (Single family or multi-family) & {$[33]$} \\
Characteristics of & Age & {$[26,32-35]$} \\
house & Garage & {$[25,34,36]$} \\
& Size/number of units of apartment complex & {$[25,26,35,36]$} \\
& Level & {$[25,26,36]$} \\
& Prospect of the river & {$[26,36]$} \\
& Administrative division & {$[36]$} \\
& Socio-economic factor (population, income, etc.) & {$[7]$} \\
\hline & CBD/Downtown (Euclidean distance) & {$[32,34-36]$} \\
& Elementry school district & {$[25,26,35]$} \\
& High school district & {$[32,36]$} \\
Characteristics of & Tax rate & {$[32,34]$} \\
& Accessibility to employment & {$[34]$} \\
& Distance to the bus stop & {$[25,35]$} \\
& Distance to the subway station & {$[26,36]$} \\
& Distance to the shopping mall & {$[25,26,35]$} \\
\hline & Relative to tree cover & {$[32,33]$} \\
& Relative to grass/lawn & {$[32,33]$} \\
& Number of trees & {$[33]$} \\
& Relative to shrub & {$[32,33]$} \\
Characteristics of & Plot tree leaf area index & {$[33]$} \\
environment & Plot tree biomass & {$[33]$} \\
& Lake (Euclidean distance) & {$[32]$} \\
& Park (Euclidean distance) & {$[25,26,32,35]$} \\
& Relative to NDVI (Normalised Difference Vegetation Index) & {$[34]$} \\
& Adjacent to moutains/rivers & {$[25]$} \\
\hline
\end{tabular}

According to the literature review, the area of a house, number of bathrooms or bedrooms, and age of apartment complex in the characteristics of house category are major factors affecting housing price. The distance to school, public transportation, and park entrance variables are also important where HPM was used. For variables that constitute major factors, those considered valid in previous studies were selected for this study. 


\section{Materials and Methods}

\subsection{Study Site and Data}

The Hangang River cuts across Seoul, and several mountains surround the city; this means that many parks and houses or apartments are close to the Hangang River or mountains and are affected by these environmental elements. To avoid the effects of the river and mountains, a study site of one of the 109 parks managed by the Seoul Metropolitan Government more than $1 \mathrm{~km}$ away from the Hangang River and the mountains was selected. As a result, Boramae Park and a residential area (Shindaebang-dong, Dongjak-gu, Seoul) around the park was selected as the study site (see Figure 1).

Boramae Park, formerly the site of the Korean Air Force Academy, was converted into a park in May 1986 and named "Boramae" for the bird used as the academy's logo. This 424,106 $\mathrm{m}^{2}$ park features sports facilities (such as an artificial grass soccer field, a basketball court, a tennis court, a badminton court, an artificial rock climbing facility, an inline skate park, an x-game ground, a track, and a gate ball ground), and recreation and leisure facilities (such as a grass plaza, a playground for children, walking paths, an air park for old fighter display, a farm experience zone, and a pond with music/floor foundation), all of which can be enjoyed by just about anyone, from children to the elderly, as a natural and cultural leisure space. Additionally, a building called the Boramae Youth Center in the park is equipped with libraries and features a variety of educational programs for adolescents [39,40].

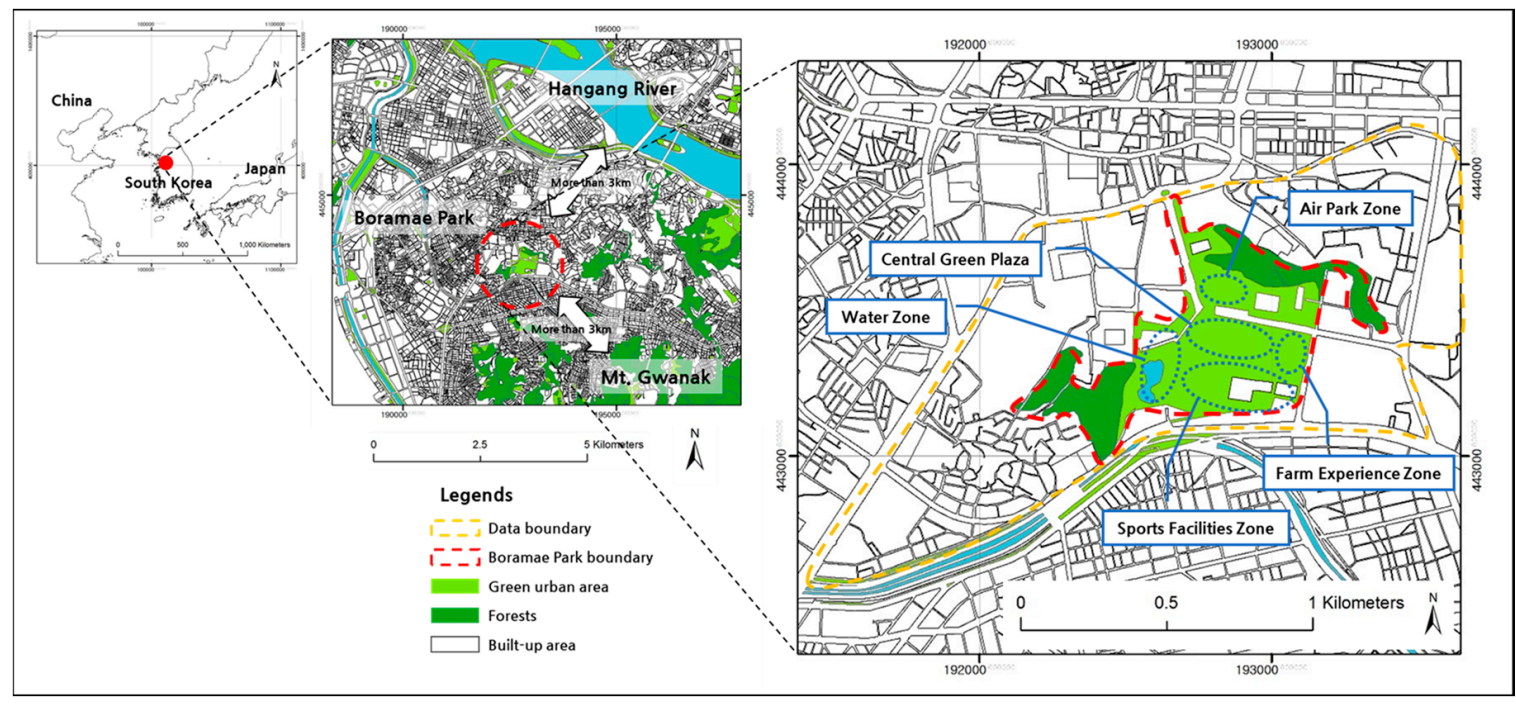

Figure 1. Study site.

The housing prices utilized for this study were the prices of houses in the neighborhood near Boramae Park of Shindaebang-dong, Dongjak-gu, Seoul and are based on the 2013 housing price data provided by the Seoul Metropolitan Government. Housing information was based on real-estate data, and the actual walking distances from house to destination rather than straight-line distances were used. This resulted in a sample size of 167 out of 421 . The mean housing price was $\$ 463,000$, and the mean walking distance to the Boramae Park was $716 \mathrm{~m}$.

To examine the difference in the recognized value of the park's cultural services by level of accessibility, the study area was divided into the well accessible zone and poorly accessible zone (see Figure 2, Table 2 and Appendix A). Accessibility refers to how easily visitors can access the park while considering obstacles such as busy roads and not simply distance. The boundaries of the two zones and the park entrances available to each zone are shown in Figure 2. The mean housing price in the well accessible zone was $\$ 460,000$ and $\$ 473,000$ in the poorly accessible zone. The well accessible zone exhibited a good accessibility condition in which a person could access the park without facing substantial obstacles such as roads, while a person had to cross a four- or more lane road at least once 
to access the park in the poorly accessible zone. The mean distance to the park was $771 \mathrm{~m}$ from the well accessible zone and $542 \mathrm{~m}$ from the poorly accessible zone with two and five entrances, respectively. Although the poorly accessible zone presented shorter distances to walk and more entrances, it was deemed poorly accessible due to the location of the busy road. This study determined that the well accessible zone presents a longer distance to walk and yet has better accessibility while the poorly accessible zone has a shorter distance but lower quality accessibility.

Table 2. Descriptive statistics of the variables.

\begin{tabular}{cccc}
\hline Variables & N & Mean & S.D. \\
\hline Price (in thousand dollars) & 167 & 463.2 & 112.0 \\
Square area of a house $\left(\mathrm{m}^{2}\right)$ & 167 & 86.9 & 22.4 \\
Floor level of a house (floor) & 167 & 11.2 & 7.2 \\
Age of a building (years) & 167 & 13.2 & 4.9 \\
Distance to the nearest bus stop (m) & 167 & 355.4 & 107.4 \\
Distance to the nearest elementary school (m) & 167 & 575.2 & 284.6 \\
Distance from the park (accessibility) (m) & 167 & 716.0 & 247.0 \\
\hline
\end{tabular}

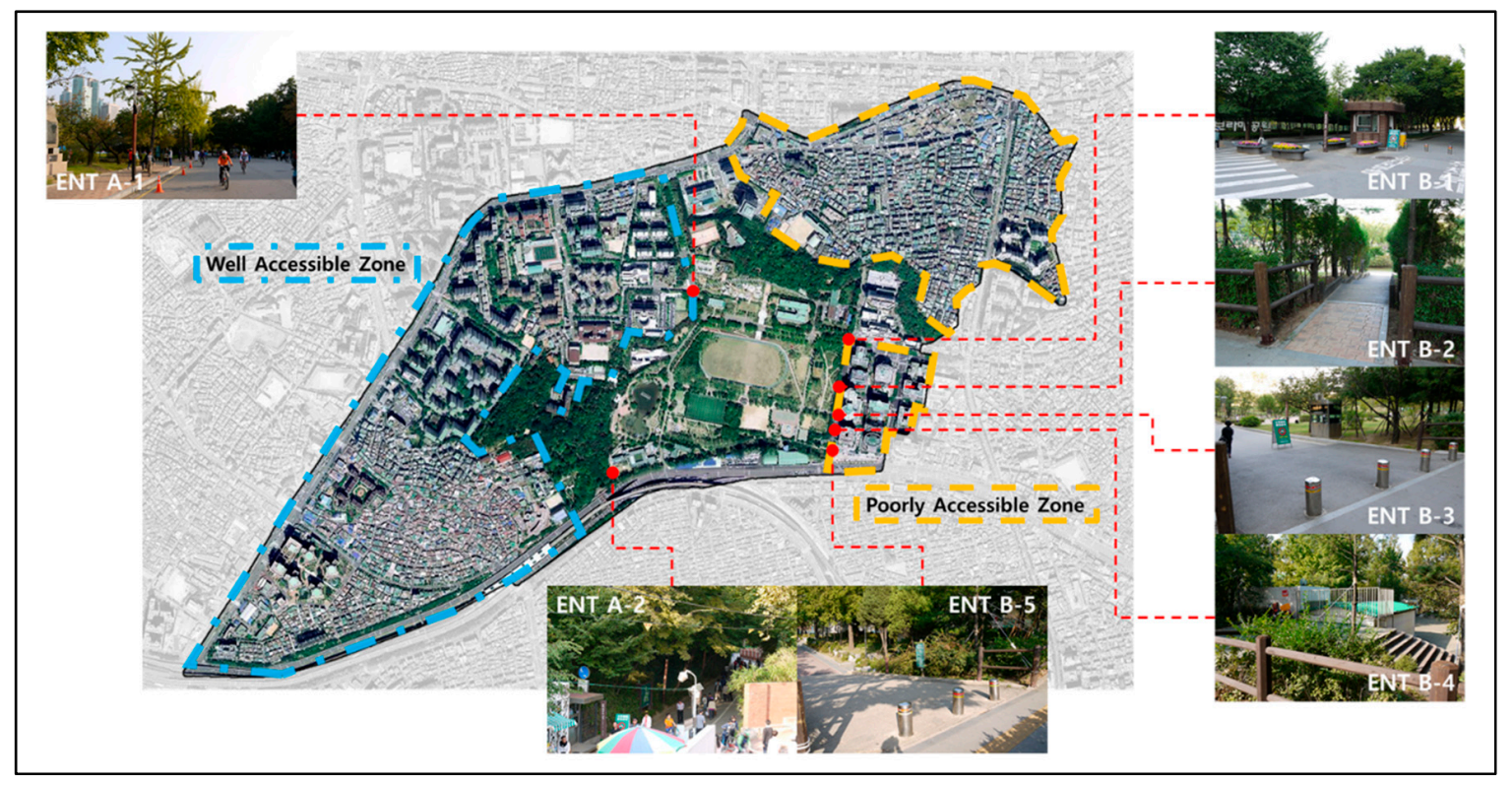

Figure 2. Entrances of the park in the well accessible zone and the poorly accessible zone.

\subsection{Methods}

This study has four phases: First, the valuation method was selected from those used for nonmarket goods. As mentioned in the literature review, the most suitable model, HPM, was selected among various non-market valuation models.

Second, variables considered to be consistent with the purpose of this study through literature review were selected. Next, interviews were conducted with two experts on the use of HPM, and the validity of the selected variables was confirmed simultaneously. The selected variables, and their modifications and uses, are as follows:

Area of a house. The areas of houses vary widely within the data, from $56.0 \mathrm{~m}^{2}$ to $132.4 \mathrm{~m}^{2}$ with an average of $86.9 \mathrm{~m}^{2}$. An analysis of the price per square meter shows that a large house will often be more expensive than a smaller house, which is typically because of the ostentation of a luxury house. Because the number of rooms and structure of the house is similar throughout Korea, only the area of a house is used in this study. Hence, the data for houses with areas that exceed $132.4 \mathrm{~m}^{2}$ are excluded to avoid bias. 
Floor level of a house. The floor level of a house within a building is a significant variable. For example, in a skyscraper, apartments located on higher floors are more expensive than those located on lower levels. This study, therefore, uses the floor level of a house as the explanatory variable.

Age of a building. The age of a building is an important variable a buyer considers when purchasing a house. Although the life expectancy of buildings in South Korea often exceeds 30 years, most people prefer newer and up-to-date buildings. Certain older apartments are excessively overpriced because of related reconstruction costs. Therefore, the dataset is limited to houses less than 20 years old.

Number of units in an apartment complex. By Korean law, "Regulations on Housing Construction Standards, Etc.," the environmental amenities or the number of convenience facilities available depends on the number of units within an apartment complex. Data on the number of units must be restrictively used because of differences in the number of units that have access to various amenities. Thus, apartment complexes that contained fewer than 500 units on site were selected.

Distance to the nearest subway station. The distance to a subway station affects the price of a house. There are five subway stations near Boramae Park, and all the distances to a station consider certain attributes including crosswalk accessibility and road width.

Distance to the nearest bus stop. Three types of bus stops are found throughout the park: the island-type bus stop that is found on medians, the general bus stop, which is found in pedestrian areas, and stops for town buses. The distance between the house and the nearest bus stop is measured regardless of bus stop type. In cases where there are multiple stops, we consider the distance to the bus stop that offers the largest number of bus lines.

Distance to the nearest elementary school. The distance to a school is another frequent consideration of house buyers. Middle school and high school students can use public transportation safely, but elementary school students tend to require additional safety precautions when commuting to school. Therefore, the distance from the house to the closest elementary school is a significant factor to consider. Elementary schools are assigned to households according to the administrative and school districts, which are often known as "catchment areas". Each school has several entrances, so the ones used most often by students are determined by field survey and considered in the study.

Distance from the park (accessibility). Boramae Park is one of the largest-scale parks in Seoul. The identification of various entrances to the park is important when estimating the distance from a house to a park. Boramae Park has seven main entrances, and the distance from a house to the park is based on the results of the field survey, which considers both crosswalks and road width in addition to actual walking distance.

We downloaded data such as price, area of a house, floor level of a house, age of a building, and number of units in an apartment complex provided by the Seoul Metropolitan Government for the use in this study. The distance to the nearest subway station, elementary school, and park entrance was measured by GIS to determine the shortest walking distance. The distance measures are based on the actual distance that the person walks considering situations such as pedestrian crossings and major roads rather than on the Euclidian distance between the two points. In particular, we considered only walking distance with the assumption that many activities, such as walking, take place in the park and the park does not have an official parking lot.

Third, the data was analyzed using log functions with HPMs. The SPSS 21 program (IBM Corporation, New York, NY, USA) was used for analysis and ordinary least squares (LS) regression for multiple regression. The stepwise method was used to select the significant variables in the HPM process. Outliers were removed using the standardized residual value and the Cook's distance.

A Pearson's product moment correlation analysis between the independent variables was performed (see Table A3 in Appendix B). If there is a high correlation between the independent variables, using the model may not produce statistically significant results even if the $\mathrm{R}^{2}$ is high. Commonly, multicollinearity can be examined by determining the value of tolerance and the variance inflation factor (VIF). If the value of tolerance exceeds 0.10 and VIF is less than 10, then 
the model is considered noncollinear. In this study, multicollinearity does not exist between the independent variables.

Finally, we plot a price curve and estimate changes in the recognition of cultural services by distance and those in the awareness of cultural services by level of accessibility. To see the differences in perception of cultural services by distance the data from 2006 to 2015 were analyzed. This is not a temporary phenomenon, but a confirmation of the steady state of residents nearby.

To identify these differences, the difference in housing price due to distance is used as willingness to pay (WTP). When HPM is used, it is necessary to assume that each individual is clearly aware of the circumstances surrounding the house and that the purchaser purchases the best housing desired [16].

In this case, if all other conditions are the same, the price of a house will change based on its accessibility from a park. If our hypothesis is correct, difference in housing price can be considered the WTP value, ceteris paribus (see Figure 3). Furthermore, the WTP value can be regarded as part of the cultural ecosystem services' value, like that of recreation activities.

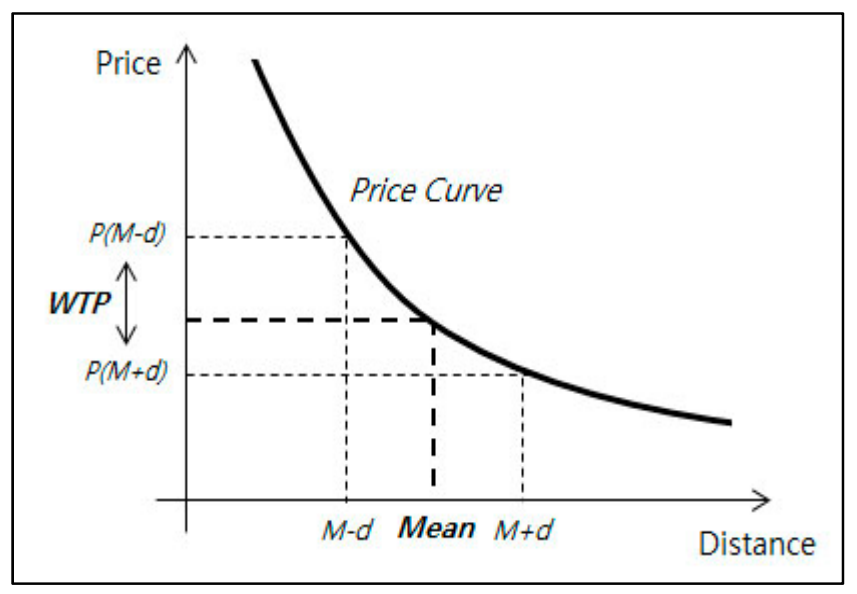

Figure 3. Willingness to pay as a function of distance from a park.

\section{Results and Discussion}

\subsection{Hedonic Price Model Results}

When setting up a model based on variables selected from the literature review and expert interviews, the model's explanatory power was significant. However, some variables were not significant at a $95 \%$ level of confidence and were eliminated from the regression analysis, resulting in the following final regression model:

$$
\begin{aligned}
& P_{i}=0.724 \times \mathrm{X}_{\text {square area }}+0.035 \times \mathrm{X}_{\text {floor level }}-0.321 \times \mathrm{X}_{\text {age of building }}- \\
& 0.187 \times \mathrm{X}_{\text {distance to the school }}-0.114 \times \mathrm{X}_{\text {distance from the park }}+0.033 \times \\
& \mathrm{X}_{\text {zone }(1 \text { or } 0)}+10.099
\end{aligned}
$$

The model was statistically significant at a $99 \%$ level of confidence $(F=470.227, p<0.0001)$ and had an $\mathrm{R}^{2}$ of 0.946 . The parameter estimate had the theoretically expected characteristics (see Table 3). All variables were significant at a $99 \%$ level of confidence, except the zone variable, which was significant at a $90 \%$ level of confidence. 
Table 3. Results of regression analysis for the effect of Boramae Park's distances.

\begin{tabular}{cccccc}
\hline Variables & Coefficient & Std. Error & $\boldsymbol{t}$-Value & Sig. & VIF \\
\hline Constant & 10.099 & 0.169 & 59.594 & 0.000 & \\
Area of a house & 0.724 & 0.019 & 37.162 & 0.000 & 1.101 \\
Floor level of a house & 0.035 & 0.006 & 5.509 & 0.000 & 1.121 \\
Age of a building & -0.321 & 0.014 & -22.220 & 0.000 & 1.770 \\
Distance to the nearest elementary school & -0.187 & 0.010 & -18.682 & 0.000 & 1.716 \\
Distance from the park & -0.114 & 0.014 & -8.130 & 0.000 & 2.068 \\
Zone (dummy) & 0.033 & 0.017 & 1.926 & 0.056 & 2.464 \\
\hline R square & \multicolumn{5}{c}{0.946} \\
F-value & \multicolumn{7}{c}{ (j70.227 (sig. 0.000) } \\
\hline
\end{tabular}

Note: We used housing price as a dependent variable and analyzed zone (dummy) variable by setting the well accessible zone to 1 and the poorly accessible zone to 0 .

Overall, increased distance from the park variable decreased property value. A one-unit increase in the distance from the park decreased the expected house value by $\$ 309$. For example, increasing the distance from the park by $100 \mathrm{~m}$ (e.g., from $200 \mathrm{~m}$ to $300 \mathrm{~m}$ ) is expected to decrease the value of the house by $\$ 11,367$, on average about $2.45 \%$ of the property value.

\subsection{Changes in the Recognition of Cultural Services by Distances}

Figure 4 shows a price curve drawn each for a well accessible zone and poorly accessible zone based on the coefficients of the estimated model. Both well and poorly accessible areas showed that the farther a house is away from the park, the lower is the price. Adjusting for the characteristics of a double-log model and comparing the prices of houses in a well accessible area near the mean distance, a housing price was $\$ 448,050$ at a distance of $716 \mathrm{~m}$. When the distance was shortened by $50 \mathrm{~m}$ the price increased by $\$ 3702$ to $\$ 451,752$; when it was $50 \mathrm{~m}$ farther the price decreased by $\$ 3425$ to $\$ 444,625$. In other words, $100 \mathrm{~m}$ from the mean distance holds a financial value of around $\$ 7127$. These changes are also similarly exhibited in poorly accessible areas.

These results imply that the difference in willingness to pay for cultural services by the distance from the park is reflected in the housing prices and that the farther the park is located from the property, the lower the WTP. That is, the distance from the park influences the recognition of cultural services.

The method used in this study was applied to data for the 10 years from 2006 to 2015, and the same results were obtained in eight year spans, such as that which includes 2007-2009 and 2011-2015. This means that the WTP difference based on distance has taken root in housing prices. A survey conducted by the municipal government found that parks and green spaces ranked eighth out of 11 items for factors that were considered when residents in a park's neighborhood chose where to live. This is in line with the model's results, which show that variables related to the structural characteristics of a house, which should directly determine the price, were valued the most, followed by the characteristics of the neighborhood in which the house is located, specifically those related to education, then by variables related to parks. Further, the survey showed that $20 \%$ of the residents enjoy outdoor activity or exercising during leisure time on weekends or holidays. Given that Boramae Park features many gym facilities, there is a relation between the cultural services provided by the park and the leisure activities in which residents choose to participate.

This conclusion is echoed by other studies. Kim [41] reports that a green area in Seoul with a size of $30,000 \mathrm{~m}^{2}$ or above has an effect on the prices of apartments in the neighborhood, with the increased value priced at $\$ 40 / 3.3 \mathrm{~m}^{2}$. Sander et al. [42] show that tree cover within 100 and $250 \mathrm{~m}$ of a house is positively correlated to price. The results showed that a $10 \%$ increase in tree cover increases average house sale price by $\$ 1371(0.48 \%)$ and $\$ 836(0.29 \%)$ in Dakota and Ramsey Counties, respectively. Sander and Haight [32] mention that the further a house is from a green space or lake, the more the housing price decreases. Thus, an owner of a single-family property in Dakota County pays more to live near these outdoor recreation areas. Unlike these studies, other reports have estimated the value 
of various green spaces. Mansfield et al. [43] analyze the impact of a variety of greenness measures on housing prices. This can be seen not only by the distance from the park, but also by various factors affecting housing prices.

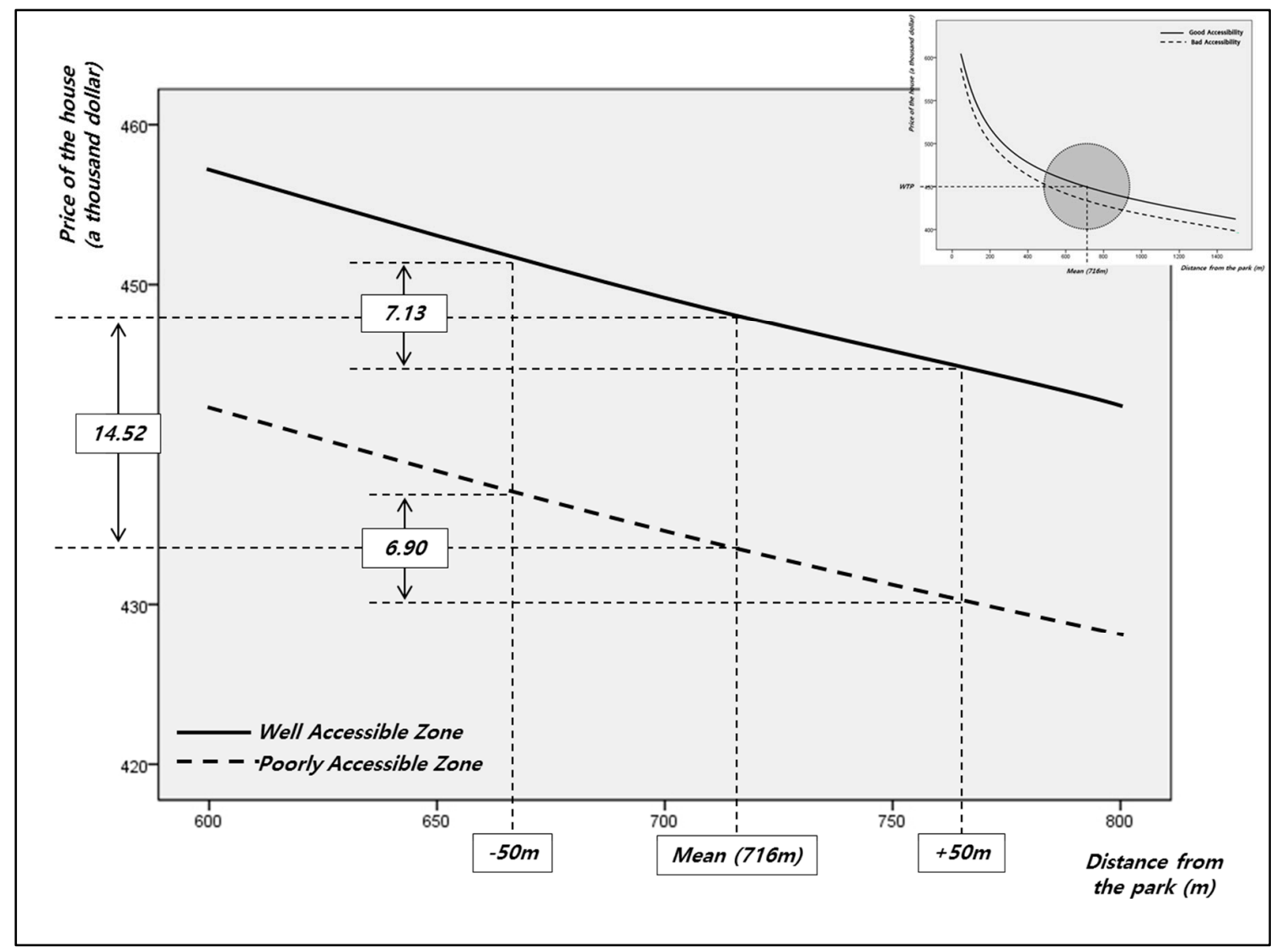

Figure 4. Change in housing price depends on distance from the park in each residential area and differences in the housing prices in two types of residential areas.

\subsection{Changes in the Awareness of Cultural Services by the Level of Accessibility}

The different prices of houses confirmed differing awareness of cultural services due to distance from a park. Further, this difference is affected not just by park distance but also by park accessibility. As mentioned earlier, accessibility refers to the level of convenience in reaching the park, which is determined by factors such as the presence of obstacles (i.e., roads) and does not simply mean the Euclidian distance from the park.

Well accessible zones and poorly accessible zones present different characteristics of accessibility. In well accessible zones, the park is reachable directly from the main gate of the apartments or by walking along a pedestrian road (see Figure 2 and Table 4). Meanwhile, poorly accessible zones present more difficulties in reaching the park, such as having to cross a four- or more lane road at least once. Simply stated, well accessible zones have pedestrian-friendly conditions as opposed to poorly accessible ones. While the well accessible zone has access to two entrances to Boramae Park, the poorly accessible zone has five entrances. Physical conditions such as mean distance and the number of entrances show that the poorly accessible zone is more advantageous in regards to parks than the well accessible zone. 
Table 4. Characteristics of the well accessible zone and the poorly accessible zone.

\begin{tabular}{c} 
Well Accessible Zone \\
\hline Access structure of well accessible zone
\end{tabular}

Nonetheless, the modeling results show that at the point of $716 \mathrm{~m}$ from the park, the housing price is $\$ 448,050$ in the well accessible zone and $\$ 433,531$ in the poorly accessible zone. That is, if the distance from the park remains the same, the price is $\$ 14,519$ higher in a well accessible zone than in a poorly accessible zone. As for the value of cultural services by the level of park accessibility, it can be concluded that the level of accessibility influences awareness of cultural services. This is because, despite further physical distance, the absence of obstacles such as busy roads makes pedestrians feel as if the park is physically closer.

Li et al. [44] investigated the impact of neighborhood walkability on property values in Austin, Texas, by using HPMs. The results show that walkable neighborhoods have greater property values than car-dependent neighborhoods. Giuliano et al. [45] mention that accessibility is capitalized into the property. The results of this study show that housing prices change by $0.01 \%-0.51 \%$ depending on accessibility. Further, Cutts et al. [46] evaluated the differences between walkability conditions and the physical activities in parks in Phoenix, Arizona. The results illustrate that residents are more likely willing to live in a walkable environment and have improved access to parks, and are more likely to use the park. Li et al. [47] examined people's preference for accessibility using the assessed property value and HPMs in Salt Lake County. The results show that the accessibility features positively influence property values. In addition to parks, research on accessibility of transportation facilities or schools shows that the better the accessibility, the higher the housing price [48-50].

Wright Wendel et al. [18] compared the accessibility of urban parks to that of neighborhood parks. The results show that there are differences in accessibility of the parks according to socioeconomic status. Omer [20] evaluated house-level accessibility to parks in Tel Aviv. His research suggested that socioeconomic factors and park access are correlated, implying the contrary: that the park accessibility can affect socioeconomics. However, according to Jim and Shan [51], the perception of the park is based on socioeconomic conditions. In this study, the economic condition of housing price and the social conditions of the surrounding area are similar. Therefore, the difference in value according to accessibility is a meaningful result. This can be exhibited in park accessibility's effect on housing prices.

\section{Conclusions}

This study examined how the perception of cultural services changes by park distance and accessibility by using the HPM. This study defined accessibility not as the Euclidian distance from the park but as the shortest walking distance a visitor would take while considering crossroads and park entrances. Therefore, study variables were selected based on a literature review and the execution of expert interviews, and an appropriate dataset was constructed. Then, the soundness of certain variables related to the location or situation was verified by executing field studies and conducting further interviews with experts.

HPM is widely used to study the value of parks and green areas, but studies have often focused on the size of park rather than residential distance from parks. Studies that focused on distance used 
the Euclidian distance, which is a straight-line distance between two points, and not the actual distance traveled by a visitor. Further, many studies pay attention to the characteristics of green spaces or parks. Contrarily, this study is based on the actual distance walked by visitors, and it was hypothesized that visitors are more aware of cultural services a park has to offer than its characteristics.

The results show that the farther a house is from the park, the more the housing price decreases; this is believed to be a change in willingness to pay based on accessibility to the park's cultural services. Presumably, the change in WTP reflects a change in the awareness of the cultural services. As for accessibility, the WTP was higher for an environment where pedestrians could access the park more easily than where their house was closer to the park but included obstacles such as busy arterial roads. Further, this shows a difference in the WTP by the level of accessibility and is a result of different awareness of cultural services.

According to the Seoul government's survey, $95 \%$ of Seoul residents were satisfied with green spaces in their neighborhood [52]. In addition, $20 \%$ of the residents were found to spend holidays or weekends exercising or engaging in outdoor activities. Further, these residents claimed that they consider environmental conditions, such as parks, neighborhood and educational conditions, when choosing a house. These results suggest that if user satisfaction were taken into account when policymakers created a park in an urban area, enhancing park accessibility would be an important criterion. Creating more entrances or locating entrances in the middle of residential areas would be effective planning decisions.

This study has a limitation with regard to the distance range in relation to the influence of the park: the houses that are located farther away from the park are not affected. If a survey captured the extent to which the park has an impact on residents' or visitors' lives, estimations of the value of the park or its WTP would be more accurate. Additionally, not all of the variable characteristics could reasonably be considered, and all the variables were assumed to be log-linear.

The results imply that there are differences in perceiving the value of the park by accessibility and that this value is reflected in housing prices. This study makes several contributions to the existing literature: first, the actual walking distance was used as a variable in the HPM, unlike previous studies which generally used Euclidean distance in hedonic models. Second, the willingness to pay for cultural services decreased as the distance increased. This is proven as not only a short-term tendency by data of a one-year period, but also a long-term phenomenon by data of a ten-year period. Lastly, we found that the difference in accessibility is inherent in apartment prices in two areas between which there is no price difference. Most previous studies show that the closer the distance, the higher the WTP. However, in this study, it was confirmed that the WTP is higher in areas with favorable pedestrian access, such as a lack of obstacles, than in those with only shorter distances.

Recently, the number of studies that attempt to quantify and evaluate ecosystems has increased worldwide. Because the results of quantification or valuation are useful to policymakers who aim to protect or preserve ecosystems and parks, we believe that this study could serve as the basis for the economic analysis of cultural ecosystem services in urban public parks. The results of this study have significant implications for urban park economic impact analyses in Seoul, and can be based on the valuation research of the ecosystem services.

Acknowledgments: This research was supported by the Korea Ministry of Environment Development of Economic Assessment Technique for Climate Change Impact and Adaptation Considering Uncertainties under Project number 2014001310010; and the BK 21 Plus Project in 2015 and 2016 (Seoul National University Interdisciplinary Program in Landscape Architecture, Global leadership program towards innovative green infrastructure).

Author Contributions: All authors have contributed to the intellectual content of this paper. Jin Han Park analyzed the data and wrote the manuscript. Chan Park and Ho Gul Kim contributed analysis tools and data. Songyi Kim contributed to data collection. Dong Kun Lee and Tae Yong Jung provided some core advice and checked through the paper's entirety.

Conflicts of Interest: The authors declare no conflict of interest. 


\section{Appendix A}

In this study, we divided and analyzed the zones. First, we statistically analyzed the differences between the two zones. Table A1 shows that the average apartment price is about $\$ 47,000$ in the poorly accessible zone and about $\$ 46,000$ in the well accessible zone. Also, when considering distance from the park, the table shows about $540 \mathrm{~m}$ and $770 \mathrm{~m}$ average distances from parks in the poorly accessible zone and the well accessible zone, respectively.

To determine whether the difference in mean values between the two regions is statistically significant, we conducted the Mann Whitney test (see Table A2). As a result, apartment price was not significant (sig.: 0.825) while distance from the park was (sig.: 0.000). This means that there is no difference in apartment price between the two zones, but there is a difference in distance from the park.

Table A1. Results of group statistics.

\begin{tabular}{lccccc}
\hline & & N & Mean & Std. Deviation & Std. Error Mean \\
\hline \multirow{2}{*}{ Price of the apartment } & Poorly Accessible & 40 & $47,265.0$ & $14,085.8$ & 2227.2 \\
& Well Accessible & 127 & $46,021.3$ & $10,174.0$ & 902.8 \\
\hline \multirow{2}{*}{ Distance from the park } & Poorly Accessible & 40 & 542.2 & 295.1 & 46.7 \\
& Well Accessible & 127 & 770.7 & 202.0 & 17.9 \\
\hline
\end{tabular}

Table A2. Results of Mann-Whitney test.

\begin{tabular}{ccc}
\hline & Price of the Apartment & Distance from the Park \\
\hline Mann-Whitney U & 2481.000 & 1349.000 \\
Wilcoxon W & $10,609.000$ & 2169.000 \\
Z & -0.221 & -4.497 \\
Asymp. Sig. (2-tailed) & 0.825 & 0.000 \\
\hline
\end{tabular}

\section{Appendix B}

A correlation analysis between variables was performed before the regression analysis. The results are shown in Table A3 below.

Table A3. Correlation coefficients.

\begin{tabular}{|c|c|c|c|c|c|c|c|}
\hline Pearson Correlation & $\begin{array}{l}\text { Price of the } \\
\text { Apartment }\end{array}$ & $\begin{array}{c}\text { Area of a } \\
\text { House }\end{array}$ & $\begin{array}{c}\text { Floor Level } \\
\text { of a House }\end{array}$ & $\begin{array}{l}\text { Age of a } \\
\text { Building }\end{array}$ & $\begin{array}{l}\text { Distance to the } \\
\text { Nearest } \\
\text { Elementary School }\end{array}$ & $\begin{array}{l}\text { Distance } \\
\text { from the } \\
\text { Park }\end{array}$ & Zone \\
\hline Price & 1.000 & 0.837 & -0.024 & -0.406 & -0.264 & -0.064 & -0.011 \\
\hline Area & 0.837 & 1.000 & -0.051 & -0.185 & -0.020 & -0.112 & -0.089 \\
\hline Floor level & -0.024 & -0.051 & 1.000 & 0.134 & 0.136 & -0.176 & 0.027 \\
\hline Age & -0.406 & -0.185 & 0.134 & 1.000 & -0.364 & -0.341 & 0.293 \\
\hline Distance to the school & -0.264 & -0.020 & 0.136 & -0.364 & 1.000 & -0.086 & -0.565 \\
\hline Distance from the park. & -0.064 & -0.112 & -0.176 & -0.341 & -0.086 & 1.000 & 0.465 \\
\hline Zone & -0.011 & -0.089 & 0.027 & 0.293 & -0.565 & 0.465 & 1.000 \\
\hline
\end{tabular}

\section{References}

1. Ministry of Environment. Ministry of Environment Promotion Plan of Main Business in 2013; Ministry of Environment: Sejong, Korea, 2013. (In Korean)

2. Lee, S.-I. A Study on sustainable urban forms for enhancing traffic avoidance-The case of the Kwangju Metropolitan Area (in Korean). J. Korea Plan. Assoc. 2000, 35, 21-33.

3. Chiesura, A. The role of urban parks for the sustainable city. Landsc. Urban Plan. 2004, 68, 129-138. [CrossRef]

4. Haase, D.; Larondelle, N.; Andersson, E.; Artmann, M.; Borgström, S.; Breuste, J.; Gomez-Baggethun, E.; Gren, Å.; Hamstead, Z.; Hansen, R. A quantitative review of urban ecosystem service assessments: Concepts, models, and implementation. Ambio 2014, 43, 413-433. [CrossRef] [PubMed] 
5. Camps-Calvet, M.; Langemeyer, J.; Calvet-Mir, L.; Gómez-Baggethun, E. Ecosystem services provided by urban gardens in Barcelona, Spain: Insights for policy and planning. Environ. Sci. Policy 2016, 62, 14-23. [CrossRef]

6. Langemeyer, J.; Baró, F.; Roebeling, P.; Gómez-Baggethun, E. Contrasting values of cultural ecosystem services in urban areas: The case of park Montjuïc in Barcelona. Ecosyst. Serv. 2015, 12, 178-186. [CrossRef]

7. Roebeling, P.; Saraiva, M.; Palla, A.; Gnecco, I.; Teotónio, C.; Fidelis, T.; Martins, F.; Alves, H.; Rocha, J. Assessing the socio-economic impacts of green/blue space, urban residential and road infrastructure projects in the Confluence (Lyon): A hedonic pricing simulation approach. J. Environ. Plan. Manag. 2016, 60, 482-499. [CrossRef]

8. De Groot, R.S.; Wilson, M.A.; Boumans, R.M.J. A typology for the classification, description and valuation of ecosystem functions, goods and services. Ecol. Econ. 2002, 41, 393-408. [CrossRef]

9. Daily, G.C.; Söderqvist, T.; Aniyar, S.; Arrow, K.; Dasgupta, P.; Ehrlich, P.R.; Folke, C.; Jansson, A.; Jansson, B.O.; Kautsky, N.; et al. Value of nature and the nature of value. Science 2000, 289, 395-396. [CrossRef] [PubMed]

10. Vandermeulen, V.; Verspecht, A.; Vermeire, B.; Van Huylenbroeck, G.; Gellynck, X. The use of economic valuation to create public support for green infrastructure investments in urban areas. Landsc. Urban Plan. 2011, 103, 198-206. [CrossRef]

11. Van Berkel, D.B.; Verburg, P.H. Spatial quantification and valuation of cultural ecosystem services in an agricultural landscape. Ecol. Indic. 2014, 37 Pt. A, 163-174. [CrossRef]

12. Bolund, P.; Hunhammar, S. Ecosystem services in urban areas. Ecol. Econ. 1999, 29, 293-301. [CrossRef]

13. Gómez-Baggethun, E.; Barton, D.N. Classifying and valuing ecosystem services for urban planning. Ecol. Econ. 2013, 86, 235-245. [CrossRef]

14. Irvine, K.N.; Warber, S.L.; Devine-Wright, P.; Gaston, K.J. Understanding urban green space as a health resource: A qualitative comparison of visit motivation and derived effects among park users in Sheffield, UK. Int. J. Environ. Res. Public Health 2013, 10, 417-442. [CrossRef] [PubMed]

15. Plieninger, T.; Dijks, S.; Oteros-Rozas, E.; Bieling, C. Assessing, mapping, and quantifying cultural ecosystem services at community level. Land Use Policy 2013, 33, 118-129. [CrossRef]

16. Daams, M.N.; Sijtsma, F.J.; van der Vlist, A.J. The effect of natural space on nearby property prices: Accounting for perceived attractiveness. Land Econ. 2016, 92, 389-410. [CrossRef]

17. Zhang, X.; Lu, H.; Holt, J.B. Modeling spatial accessibility to parks: A national study. Int. J. Health Geogr. 2011, 10, 1. [CrossRef] [PubMed]

18. Wright Wendel, H.E.; Zarger, R.K.; Mihelcic, J.R. Accessibility and usability: Green space preferences, perceptions, and barriers in a rapidly urbanizing city in Latin America. Landsc. Urban Plan. 2012, 107, 272-282. [CrossRef]

19. Nicholls, S. Measuring the accessibility and equity of public parks: A case study using GIS. Manag. Leis. 2001, 6, 201-219. [CrossRef]

20. Omer, I. Evaluating accessibility using house-level data: A spatial equity perspective. Comput. Environ. Urban Syst. 2006, 30, 254-274. [CrossRef]

21. Wolch, J.; Wilson, J.P.; Fehrenbach, J. Parks and park funding in Los Angeles: An EQUITY-MAPPING ANALYSIS. Urban Geogr. 2013, 26, 4-35. [CrossRef]

22. Strand, J.; Vågnes, M. The relationship between property values and railroad proximity: A study based on hedonic prices and real estate brokers' appraisals. Transportation 2001, 28, 137-156. [CrossRef]

23. Luttik, J. The value of trees, water and open space as reflected by house prices in the Netherlands. Landsc. Urban Plan. 2000, 48, 161-167. [CrossRef]

24. Jim, C.Y.; Chen, W.Y. Impacts of urban environmental elements on residential housing prices in Guangzhou (China). Landsc. Urban Plan. 2006, 78, 422-434. [CrossRef]

25. Ko, H.-J.; Yun, K.-B.; Shim, Y.-J.; Hwang, H.-Y. Impact analysis of an eco-park on the adjacent apartment unit price by using the hedonic model. J. Korean Hous. Assoc. 2011, 22, 47-57. [CrossRef]

26. Oh, D.-H.; Lee, C.-B. An Analysis on the effect of view and story on the price of Hanriver Riverside apartments. J. Korea Plan. Assoc. 2003, 38, 247-257.

27. Jang, Y. Valuing the Green-Zone in the City of Seoul and Willingness to Pay of Citizen; Graduate School of Yonsei University: Seoul, Korea, 2005. 
28. Freeman, M., III; Herriges, J.A.; Kling, C.L. The Measurement of Environmental and Resource Values: Theory and Methods; Routledge: Abingdo, UK, 2010.

29. Kwon, O.-S. Environmental Economics; Pakyoungsa: Seoul, Korea, 2007.

30. Tietenberg, T.H.; Lewis, L. Environmental and Natural Resource Economics; Routledge: Abingdo, UK, 2016.

31. Brander, L.; Brouwer, R.; Wagtendonk, A. Economic valuation of regulating services provided by wetlands in agricultural landscapes: A meta-analysis. Ecol. Eng. 2013, 56, 89-96. [CrossRef]

32. Sander, H.A.; Haight, R.G. Estimating the economic value of cultural ecosystem services in an urbanizing area using hedonic pricing. J. Environ. Manag. 2012, 113, 194-205. [CrossRef] [PubMed]

33. Escobedo, F.J.; Adams, D.C.; Timilsina, N. Urban forest structure effects on property value. Ecosyst. Serv. 2015, 12, 209-217. [CrossRef]

34. Payton, S.; Lindsey, G.; Wilson, J.; Ottensmann, J.R.; Man, J. Valuing the benefits of the urban forest: A spatial hedonic approach. J. Environ. Plan. Manag. 2008, 51, 717-736. [CrossRef]

35. Kim, Y.-J.; Kim, K.-H. Valuation of Urban Leisure Parks: An Application of Hedonic Price Model. J. Tour. Sci. 2007, 31, 265-286.

36. Hwnag, H.-K.; Lee, C.-M.; Kim, M.-K. Effect of visibility of the Han River on housing price. Hous. Stud. Rev. 2008, 16, 51-72.

37. Bockstael, N.; McConnell, K.E. Environmental and Resource Valuation with Revealed Preferences: A Theoretical Guide to Empirical Models; Springer: Berlin, Germany, 2007; Volume 7.

38. Kim, S.; Lee, S.; Yoon, Y.; Kwak, S.; Eom, Y.; Kim, Y.; Cho, S.; Ryu, M. The Measurement of Environmental E Resource Values: Method and Application; Korea Research Institute for Human Settlements: Sejong, Korea, 2005; (http:/ /library.krihs.re.kr/upload/publication/publication/RR2004-12.pdf).

39. Seoul Metropolitan Government. Hundred Parks in Seoul; Seoul Metropolitan Government: Seoul, Korea, 2008.

40. Seoul Metropolitan Government. Boramae Park. Available online: http://parks.seoul.go.kr/template/ default.jsp?park_id=boramae (accessed on 5 December 2016).

41. Kim, D.-J. Influence of urban green space environment on the value of residential properties: The case of apartment in Seoul. Korean J. For. Econ. 2002, 10, 8-19.

42. Sander, H.; Polasky, S.; Haight, R.G. The value of urban tree cover: A hedonic property price model in Ramsey and Dakota Counties, Minnesota, USA. Ecol. Econ. 2010, 69, 1646-1656. [CrossRef]

43. Mansfield, C.; Pattanayak, S.K.; McDow, W.; McDonald, R.; Halpin, P. Shades of green: Measuring the value of urban forests in the housing market. J. For. Econ. 2005, 11, 177-199. [CrossRef]

44. Li, W.; Joh, K.; Lee, C.; Kim, J.H.; Park, H.; Woo, A. Assessing benefits of neighborhood walkability to single-family property values: A spatial hedonic study in Austin, Texas. J. Plan. Educ. Res. 2015, 35, 471-488. [CrossRef]

45. Giuliano, G.; Gordon, P.; Qisheng, P.; Park, J. Accessibility and Residential Land Values: Some Tests with New Measures. Urban Stud. 2010, 47, 3103-3130. [CrossRef]

46. Cutts, B.B.; Darby, K.J.; Boone, C.G.; Brewis, A. City structure, obesity, and environmental justice: An integrated analysis of physical and social barriers to walkable streets and park access. Soc. Sci. Med. 2009, 69, 1314-1322. [CrossRef] [PubMed]

47. Li, H.; Wei, Y.D.; Yu, Z.; Tian, G. Amenity, accessibility and housing values in metropolitan USA: A study of Salt Lake County, Utah. Cities 2016, 59, 113-125. [CrossRef]

48. Munoz-Raskin, R. Walking accessibility to bus rapid transit: Does it affect property values? The case of Bogotá, Colombia. Transp. Policy 2010, 17, 72-84.

49. Chin, H.C.; Foong, K.W. Influence of school accessibility on housing values. J. Urban Plan. Dev. 2006, 132, 120-129. [CrossRef]

50. Geurs, K.T.; van Wee, B. Accessibility evaluation of land-use and transport strategies: Review and research directions. J. Transp. Geogr. 2004, 12, 127-140. [CrossRef]

51. Jim, C.; Shan, X. Socioeconomic effect on perception of urban green spaces in Guangzhou, China. Cities 2013, 31, 123-131. [CrossRef]

52. Seoul Metropolitan Government. Seoul Statistics. Available online: http://stat.seoul.go.kr/ (accessed on 5 December 2016).

(C) 2017 by the authors; licensee MDPI, Basel, Switzerland. This article is an open access article distributed under the terms and conditions of the Creative Commons Attribution (CC BY) license (http:/ / creativecommons.org/licenses/by/4.0/). 